\title{
De kracht van de gekleurde bril
}

\section{Implicaties van religieus pluralisme op de levensovertuiging van gelovigen, atheïsten en spirituelen}

\author{
Anneke Pons-de Wit*
}

\section{Summary}

It is a mainstay in the sociology of religion that the reflexivity that appears in religious pluralist societies has an impact on the religious identity of individuals. According to Peter Berger, reflexivity replaces the certainty of the taken-for-granted worldview by enduring uncertainty, hence relativizing every religious identity. However, his theory is underdeveloped concerning the role of culture. He fails to describe how worldviews not just respond to the pressure to relativize, but are already involved in the definition, interpretation, and integration of reflexivity itself. The aim of this article is to study the role of the worldview in dealing with reflexivity more thoroughly. A comparison between the religious trajectories of religious, atheist, and spiritual individuals, demonstrates that their own worldview restricts the scope of reflexivity letting it ending up in purification instead of relativization of religious identities.

\section{Inleiding}

'Er is waarschijnlijk geen God. Durf zelf te denken en geniet van het leven', zo vertelde een billboard in 2009 de vele automobilisten die dagelijks de A4 bij Schiphol passeerden. Het initiatief voor deze campagne kwam van enkele atheïsten die graag een zelfbewust atheïsme willen promoten. De term 'waarschijnlijk' verwijst naar een vast geloof in de wetenschappelijke methode die kennisclaims beoordeelt op de schaal van waarschijnlijk tot onwaarschijnlijk. De claim van het bestaan van een godheid is voor Floris van den Berg (één van de initiatiefnemers van deze campagne) zo onwaarschijnlijk dat hij zichzelf een "zelotisch atheïst en humanist" noemt. De religieuzen in Nederland laten zich niet onbetuigd en reageren al snel met een billboard langs de A28 die de tekst bevat "Er is waarlijk één God. Durf te geloven en geniet ook het

* Anneke Pons-de Wit is als promovenda verbonden aan het Centrum voor Sociologisch Onderzoek van de Katholieke Universiteit Leuven. 
leven na dit leven". Weer andere Nederlanders zetten zich af tegen zowel gelovigen als atheïsten door vooral in zichzelf te geloven. Hun tijdlijn op sociale media is gevuld met spreuken die de bezoeker tot vervelens toe oproepen om 'jezelf te zijn' en 'je hart te volgen'. Deze uiteenlopende voorbeelden van levensbeschouwelijke uitingen laten zien dat de Nederlandse samenleving religieus zeer pluralistisch is. De stelligheid waarmee de aanhangers van diverse levensovertuigingen hun standpunten formuleren doet tevens vermoeden dat ze allemaal zeer overtuigd zijn van hun eigen gelijk.

Dat zelfverzekerde varianten van levensovertuigingen goed gedijen in religieus pluralistische samenlevingen wordt steeds meer bevestigd in religiewetenschappelijk onderzoek. Diverse studies laten zien dat juist het besef dat veel Amerikanen hun wereldbeeld niet delen Amerikaanse Evangelicals ertoe aanzet om fundamentalistisch te worden en de absolute status van hun dogma's nog meer te benadrukken (Ammerman 1987; Smith 1998). Ook onder moslims blijkt een dieper besef van de religieuze diversiteit in de samenleving de gelovigen alleen maar meer te overtuigen van hun eigen gelijk (Peek 2005; Beekers 2015). Naast de geloofsafval die zeker plaatsvindt, zijn er in westerse samenlevingen dus gelovigen die alleen maar zelfbewuster en strikter lijken te worden. Dezelfde beweging is waarneembaar bij andere levensovertuigingen. Geïnspireerd door vooraanstaande atheïsten zoals Richard Dawkins en Christopher Hitchens is er bijvoorbeeld in de afgelopen decennia een zogenaamde Nieuwe atheïstische beweging ontstaan (Bullivant 2012; Ribberink $\&$ Houtman 2010). Deze atheïsten zijn, net als fundamentalistische gelovigen, zelfbewust en zeker van hun anti-religieuze wereldbeeld (Hunsberger \& Altemeijer 2006; Ribberink, Achterberg \& Houtman 2013; Smith 2011).

De bevinding dat individuen die leven in een pluralistische context zo vast overtuigd raken van hun wereldbeeld valt lastig te begrijpen vanuit de gangbare theorie van Berger (1969; 2014; cf. Berger, Berger \& Kellner 1973) over religieuze verandering op het individuele niveau. Deze theorie, die zowel in de godsdienstsociologie (Woodhead \& Heelas 2000; Bruce 2002) als in de bekeringsliteratuur (Rambo 1993) algemeen is aanvaard, veronderstelt dat de levensovertuigingen van individuen juist worden gerelativeerd. Religieus pluralisme wordt volgens Berger op het individuele niveau vertaald naar reflexiviteit. De wetenschap dat er alternatieve wereldbeelden zijn, zorgt ervoor dat individuen het eigen wereldbeeld niet langer vanzelfsprekend vinden en reflexieve vragen gaan stellen over de plausibiliteit ervan. De traditionele levensbeschouwelijke autoriteiten kunnen die vragen niet oplossen, omdat zij hun absolute zeggingskracht hebben verloren in een religieus pluralistische omgeving (cf. Chaves 1994; Yamane 1997; Wilson 1982). Individuen zijn dus 
op zichzelf aangewezen om een keuze te maken. Een keuze, die nooit meer absoluut kan zijn omdat die altijd vanuit de wetenschap wordt genomen dat het slechts één van de vele opties is. In zijn vroege werk $(1969 ; 1973)$ gaat Berger ervan uit dat deze ondermijning van de plausibiliteit van religies uitmondt in secularisering. Later komt hij daarop terug en stelt hij dat de reflexiviteit die religieus pluralisme bij individuen oproept blijvende twijfel en relativering van elke levensovertuiging tot gevolg heeft (Berger 2014; cf. Berger \& Zijderveld 2009; Marti 2015).

Het bestaan van vormen van fundamentalisme in een pluralistische omgeving wordt door aanhangers van deze relativeringstheorie verklaard als een reactie op relativisme (Berger 1979; Berger \& Zijderveld 2009). Angst voor juist die blijvende twijfel die een reflexieve benadering van de eigen levensovertuiging met zich mee zou brengen, zou sommigen ertoe aanzetten om de absolute waarheid van de eigen dogma's meer te benadrukken en een striktere identiteit te ontwikkelen dan traditionele (on)gelovigen. Daarom noemt Ammerman uitingen van religieus fundamentalisme "a defense against the terrible chaos they perceive in the modern world" (Ammerman 1987, 51; cf. Lawrence 1989; Lechner 1985). Ook het ontstaan van de anti-religieuze variant van atheïsme wordt vaak gekoppeld aan een ervaren bedreiging vanuit religies (e.g. Ribberink, Achterberg \& Houtman 2013; Cimino \& Smith 2007). Fundamentalisme is volgens deze verklaring dus eigenlijk een moreel verwerpen van de relativering die religieuze reflexiviteit met zich meebrengt. Het probleem is echter dat hiermee niet valt te begrijpen waaróm sommigen in reactie op religieuze reflexiviteit zo vast overtuigd raken van hun eigen wereldbeeld, terwijl anderen die meer zouden gaan relativeren. Daarnaast valt op basis van de relativeringstheorie moeilijk uit te leggen waarom sommigen hun oude levensovertuiging niet slechts relativeren, maar verruilen voor een andere. Hoewel verschillende reacties op de vermeende relativerende werking van religieuze reflexiviteit mogelijk worden geacht, is vanuit de theorie zelf geen ruimte voor het begrijpen van deze verschillen. De enige theoretisch logische uitkomst blijft de relativering van elke levensovertuiging.

Dat er in de relativeringstheorie geen ruimte is om verschillen te begrijpen komt omdat er te weinig aandacht is voor de rol van het eigen wereldbeeld in het omgaan met reflexiviteit. Zoals Berger zelf uitlegt in The social construction of reality (Berger \& Luckmann 1966) wordt het gedrag van mensen bepaald door sociaal geconstrueerde en gedeelde betekenissystemen waarvan het wereldbeeld de basis is (Campbell 2007). Het eigen wereldbeeld zorgt dus voor de bril waardoor individuen naar de wereld, en dus ook naar reflexiviteit, kijken. In de relativeringstheorie wordt aangenomen dat dit eigen wereldbeeld enkel 
een rol speelt in reactie op relativering en niet in de relatie tussen reflexiviteit en relativering zelf. De gekleurde bril van het eigen wereldbeeld wordt echter niet pas opgezet om te reageren op de relativerende werking van reflexiviteit, maar is al actief betrokken bij het definiëren, interpreteren en verwerken van reflexiviteit zelf. Het is precies die actieve rol van het eigen wereldbeeld in het omgaan met de religieuze reflexiviteit die in dit artikel nader wordt bekeken. Daarvoor is het nodig de relativeringstheorie van Berger opnieuw te bevragen. Door de actieve rol van het eigen wereldbeeld in het omgaan met religieuze reflexiviteit is het immers maar de vraag of en hoe religieuze reflexiviteit leidt tot relativering. De vraag die concreet beantwoord zal worden luidt daarom: Op welke wijze bepaalt het eigen wereldbeeld de invloed die religieuze reflexiviteit heeft op de levensbeschouwelijke trajecten van individuen?

\section{Data beschrijving}

De hierboven gestelde vraag zal worden beantwoord op basis van de analyse van 51 biografische interviews die in de periode 2015-2017 gehouden $z^{2 i j n^{2}}$ met individuen die gelovig (14), atheïstisch (19) of spiritueel (18) zijn. Onder hen zijn nagenoeg evenveel mannen als vrouwen (25 versus 26 ) en de meesten zijn hoger opgeleid (HBO of WO). Alle respondenten zijn tussen de 25-45 jaar oud, opgegroeid in Nederland en wonen nu in de Randstad. Het leeftijdscriterium is gesteld om ervoor te zorgen dat de respondenten in dezelfde periode, namelijk in een reeds ontzuilde Nederlandse samenleving, zijn opgegroeid. Samen met de eis van wonen in de Randstad zorgt dat ervoor dat ze allemaal zijn blootgesteld aan religieus pluralisme. De gelovigen zijn benaderd via bestaande contacten in de zogenaamde Dutch Biblebelt, en de spirituele respondenten via connecties in oecumenische kerkelijke gemeenten. Dat betekent overigens niet dat de spirituele respondenten zelf altijd verbonden zijn aan een oecumenische gemeente. De contacten met de atheïsten zijn gelegd via berichten in atheïstische facebookgroepen zoals de Dutch Atheists en tijdens het bezoeken van Verlichtingsborrels die georganiseerd worden door de nieuw atheïstische organisatie De Vrije Gedachte. In alle gevallen is ook gebruik gemaakt van de methode van snowball sampling, waarbij via respondenten contact werd gelegd met nieuwe respondenten. Er is altijd gezorgd voor voldoende variatie door niet meer dan twee respondenten uit één levensbeschouwelijke gemeenschap (bijvoorbeeld een kerkelijke gemeente) te selecteren. 
Voor dit artikel is niet de huidige levensovertuiging, maar de levensbeschouwelijke startpositie het uitgangspunt. Een overzicht van de trajecten van de respondenten is te vinden in de bijlage. Daarin is te zien dat de meeste gelovigen ook gelovig zijn opgegroeid. Onder de atheïsten en de spirituelen heeft de helft dezelfde levensbeschouwelijke achtergrond als vroeger. Hun wereldbeeld is dus niet veranderd. Daarnaast zijn er onder zowel de atheïsten als spirituelen die gelovig of religieus onverschillig zijn opgegroeid. De respondenten verschillen dus op twee punten van elkaar. Enerzijds zijn er verschillen in de levensovertuiging waarmee ze zijn opgegroeid en die ze nu hebben. Dat maakt de data uitermate geschikt om de invloed van het eigen wereldbeeld op de definitie en verwerking van religieuze reflexiviteit te onderzoeken. Daarnaast bestaat er onder de gelovigen een verschil tussen hen die gelovig zijn gebleven (hierna te noemen 'blijvers') en zij die veranderd zijn (hierna te noemen 'afhakers'). Bij de gelovigen kan dus tevens gekeken worden of de invloed van het eigen wereldbeeld verschillend is bij blijvers en afhakers. De veranderingstrajecten van degenen die vroeger religieus onverschillig waren (waardoor ze naar eigen zeggen geen wereldbeeld hadden) zijn in dit artikel buiten beschouwing gelaten.

Uiteraard bestaat er binnen elke levensbeschouwelijke categorie diversiteit op allerlei vlakken. Wat alle gelovigen echter delen is de overtuiging dat er een transcendente God bestaat die via de Bijbel of de kerk absolute autoriteit heeft over hun leven. De atheïsten veronderstellen daarentegen dat kennis over de humanistische waarheid alleen verkregen kan worden door de wetenschappelijke methode. Volgens de spirituele respondenten bestaat er geen waarheid buiten de spirituele ervaringen van individuen, die voor hen dan ook de absolute autoriteit hebben. Wat zij daarom met elkaar delen is een holistisch wereldbeeld en een 'bricolage' aan inspiratiebronnen (cf. Houtman \& Tromp 2020). Deze laatste spirituele categorie is bijzonder interessant, omdat deze levensovertuiging de positie die uit de relativeringstheorie lijkt voort te vloeien het dichtst benadert. Relativistische varianten van levensovertuigingen zouden gekenmerkt worden door inclusivisme en een 'bricolage' aan inspiratiebronnen (Berger \& Zijderveld 2009), iets wat Pfadenhauer (2016) 'hybridization' noemt. Zoals blijkt uit de eerdere genoemde gedeelde dogma's van de spirituele respondenten is de spirituele levensovertuiging echter geen relativistische variant van andere overtuigingen ${ }^{3}$, maar heeft unieke en gedeelde ontologische en epistemologische dogma's waarmee ze zich onderscheidt van haar (niet)religieuze equivalenten (cf. Aupers \& Houtman 2006; Campbell 2007). Desalniettemin is het in het licht van de relativeringstheorie 
zinvol om te vergelijken tussen levensovertuigingen die religieuze diversiteit verwerpen (religie en atheïsme) en die het juist omarmen.

De analyse van de interviews heeft plaatsgevonden op basis van de volledige transcriptie van de interviews. Met behulp van het analyseprogramma Atlas. ti zijn deze transcripties gecodeerd. Om verandering van de trajecten goed in kaart te brengen is de analyse uitgevoerd op drie niveaus. In eerste instantie zijn de veranderingen die de respondenten zelf rapporteren systematisch in kaart gebracht. Vervolgens is gekeken of deze veranderingen leidden tot een ander wereldbeeld, en welke redenen worden opgegeven voor het wel of niet veranderen. Voor dit tweede niveau zijn de definities van het heilige en van de autoriteitsbronnen in elke periode van het traject gecodeerd en de motivaties die gegeven worden voor het al dan niet veranderen daarvan. Tenslotte is gekeken naar interne veranderingen in (het omgaan met) de eigen levensovertuiging en de redenen die daarvoor gegeven worden. Een systematische vergelijking tussen de trajecten van de respondenten op alle analyseniveaus heeft de onderstaande resultaten opgeleverd.

\section{Kritisch leren denken}

Nienke en Rianne zijn twee respondenten die gelovig zijn opgevoed. Hun verhalen over hun religieuze ontwikkeling vertonen een opmerkelijke gelijkenis, die in de volgende fragmenten naar voren komt:

Nienke: In eerste instantie werd ik meer kritisch [en ging vragen stellen als] 'wat vind ik daar nou van?' Een eigen mening ontwikkelen [dus] (...) In het gezin waar ik vandaan kom ging het daar eigenlijk nooit over. We gingen gewoon naar de kerk, dat was vanzelfsprekend (...) Dat werd allemaal klakkeloos aangenomen.

Rianne: Het was wel een periode waarin ik zelf ging nadenken (...) ik wilde gewoon weten van: 'Is datgene wat ik denk dat ik geloof, ís dat ook wat ik geloof? Klopt dat eigenlijk wel?’

Beiden beschrijven hier de ontwikkeling van een reflexieve houding. Ze zijn opgevoed met het idee dat hun geloof vanzelfsprekend was, maar zijn op een gegeven moment gaan twijfelen en zich af gaan vragen of datgene waar ze altijd vast van overtuigd zijn geweest wel waar is. Deze bevinding is in overeenstemming met de verandering naar reflexiviteit die verondersteld wordt in de relativeringstheorie. Opmerkelijk is wel dat Nienke en Rianne met deze zelfde 
reflexieve houding een verschillende kant zijn opgegaan. Voor Nienke was het de eerste opmaat tot het verliezen van haar geloof, terwijl het voor Rianne een startpunt was voor een verdieping ervan.

De verandering van een vanzelfsprekende naar een reflexieve houding richting de eigen levensovertuiging is een algemene trend onder de respondenten. Vrijwel alle respondenten, ongeacht het wereldbeeld dat ze aanhangen of ze wel of niet bij hun oude wereldbeeld zijn gebleven, beschrijven deze verandering en achten die cruciaal voor hun levensbeschouwelijke ontwikkeling. Het spirituele wereldbeeld van Trijntje is inhoudelijk niet veel veranderd, maar toch zegt ook zij dat haar leven "180 graden omgegooid" is door de verandering van "héél, héél erg onbewust geloof in mijn jonge jaren" naar "heel bewust nadenken" daarover. Hetzelfde geldt voor atheïst Tineke die eerst "gewoon [haar] leven leefde" en daar verder niet over nadacht, maar zich op een gegeven moment ging afvragen "Heb ik eigenlijk een levensbeschouwing of een visie?". Enkele respondenten geven aan deze verandering niet doorgemaakt te hebben, omdat ze als kind hebben geleerd om "na te denken over geloof" (Sietske, religieus). "Ik werd thuis uitgedaagd tot denken" en "heb geleerd om alles te bevragen", vertelt ook Aimé (atheist). Zij zijn dus, in tegenstelling tot de anderen, al opgevoed met een reflexieve kijk op religieuze identiteit. Deze cases laten zien dat reflexiviteit niet louter verklaard kan worden vanuit de ontwikkelingspsychologie, maar ook een culturele norm is die dus, zoals Berger ook veronderstelt, sterker blijkt te zijn geworden in de levensbeschouwelijke identiteit van individuen met allerlei verschillende levensovertuigingen. Een culturele norm waardoor respondenten kritisch gaan nadenken over hun eigen religieuze identiteit.

\section{Wereldbeeld gebonden vragen}

In de manier waarop reflexiviteit tot uiting komt onder de gelovige respondenten is echter iets opmerkelijks aan de hand. Dat blijkt uit de manier waarop Rhodé (blijver) in het volgende citaat haar reflexieve vragen verwoordt:

Op een gegeven moment had ik zoiets van: Ja, wat is nou eigenlijk de waarheid? Aan de ene kant [had ik geleerd]: dit is de weg. En aan de andere kant [begon ik te denken]: Wat staat er nou in de Bijbel?

Waar de eerste vraag van Rhodé een algemene reflexieve vraag naar waarheid is, versmalt ze die in haar tweede vraag automatisch tot een vraag die gaat 
over de waarheid volgens de Bijbel. Deze versmalling is exemplarisch voor de gelovigen en laat zien dat de Bijbel en ook het bestaan van God ontsnapt aan hun reflexiviteit. Roos heeft veel normen en tradities kritisch bevraagd, maar "ik heb nooit getwijfeld aan Gods bestaan, en nooit getwijfeld of de bijbel waar was of niet”, zegt ze resoluut. Typische reflexieve vragen van de gelovige respondenten gaan dan ook over "Wat wil God met mijn leven verder? (...) Wat is bijbels?" (Taco), en "hoe beïnvloed ik dat ik de Heere vind in mijn leven?" (Renske). Ze laten zien dat de culturele bril van het eigen wereldbeeld ervoor zorgt dat het bestaan van God en de autoriteit van de Bijbel aan de kritiek ontsnapt, en dat deze onbetwijfelde waarheden daardoor zelfs de norm bepalen van de reflexieve zoektocht naar waarheid. Dat geldt voor zowel de blijvers als de latere afhakers onder de gelovigen. Ook bij Anna (nu atheïst) en Dirk (nu spiritueel) hadden de reflexieve vragen respectievelijk tot doel "om de bijbel te begrijpen”, en te ontdekken "hoe je Gods stem kan verstaan en kan ontdekken wat Hij bedoelt en wat Hij wil met je leven". Reflexiviteit was voor hen dus niet de reden om te gaan twijfelen aan de centrale dogma's van hun geloof.

Ook bij de atheïstische en spirituele respondenten zorgt het eigen wereldbeeld ervoor dat de belangrijkste aannames daarin aan de reflexieve bevraging ontsnappen. De vragen van de atheïsten draaien rondom het vinden van "concrete dingen" (Ralf). Iets wat Rick verder specificeert als "wetenschappelijk met alles omgaan: met onderbouwingen, vooral veel proeven doen, laten zien dat het ook echt zo is". Dat deze wetenschappelijke manier de enige juiste manier is om waarheid te vinden, staat voor hen echter buiten kijf. "Er bestaat geen betere methode”, zo luidt de eenvoudige motivatie van Nico. De spirituele Lara, die opgevoed is in een oecumenische gemeenschap met een open blik naar allerlei manieren van geloofsbeleving, gaat op het moment dat ze reflexief wordt "alles in twijfel trekken" en zich afvragen "wat voor soort geloof past bij mij?”. Erwin geeft een interessante reden voor het feit dat ook hij "gewoon niet wist wat te geloven" toen hij reflexief ging nadenken. Dat was volgens hem omdat hij de verschillende levensbeschouwelijke verhalen uit zijn jeugd "nooit als dogmatiek, als geloofswijze” heeft meegekregen. De verwijzing naar anti-dogmatisme maakt expliciet dat de vraag of er wel meerdere waarheden bestaan niet ter discussie gesteld wordt door de spirituele respondenten, terwijl dat anti-dogmatisme nu precies een belangrijke veronderstelling binnen het spirituele wereldbeeld is. Hun reflexiviteit wordt bovendien versmald tot de eigen ervaring, die zelf niet bevraagd wordt. "Ik ben een gevoelsmens [... en] ik vóel God in me. Dan is er toch geen twijfel meer, dan wéét je toch dat Hij er is", motiveert Lydia simpelweg. Zoals bij gelovige respondenten de autoriteit van de Bijbel niet wordt betwijfeld en bij 
de atheïstische respondenten de autoriteit van de wetenschap buiten schot blijft, blijft de autoriteit van de eigen ervaring bij de spirituele respondenten dus gevrijwaard van kritische vragen. Het eigen wereldbeeld van de respondenten blijkt de reflexiviteit te beperken en zelfs de norm te bepalen voor de reflexieve zoektocht naar waarheid.

\section{Zoeken onder gelijkgestemden}

Het type reflexieve vragen dat de respondenten stellen, beperkt eveneens de bronnen waarin ze hun antwoorden zoeken. Het is immers logisch dat gelovigen, die zoeken naar een bijbelse onderbouwing van hun normen en tradities "de bijbel [gaan] lezen en [zich] afvragen of daar een antwoord in staat" (Taco). De reflexieve vragen van de atheïsten brengen hen bij wetenschappelijke bronnen. Nico ging bijvoorbeeld The God Delusion lezen en kijken naar de online video's van schrijver Richard Dawkins, welke keuze hij motiveert met: “Ja, dat is zo'n beetje de canon van de atheïst: daarom ging ik dat lezen”. Onder de spirituele zoekers is de diversiteit aan inspiratiebronnen groter. Erwin heeft zich bijvoorbeeld verdiept in minstens tien verschillende tradities, variërend van de liberale katholieke traditie waarin hij is opgegroeid, tot theosofie, paranormale media en een aan het hindoeïsme gelieerde spirituele stroming. Hij noemt het zelf echter een verdieping in "dingen die je wel wist", waaruit blijkt dat hij al deze tradities beschouwt als onderdeel van zijn eigen wereldbeeld. Dat komt overeen met het typische spirituele idee wat Lydia verwoordt als dat "alle geloven op deze wereld allemaal hetzelfde zijn".

De voorkeur van atheïst Nico voor Dawkins heeft ook te maken met de behoefte dat de bronnen "lijken op waar ik thuis [aan gewend was] qua openheid en dat dingen niet opgelegd worden”, om met de woorden van Lara (spiritueel) te spreken. Ze deelt deze behoefte met de gelovigen die eveneens onder wat Taco noemt "gelijkgestemden" zoeken naar interpretaties van de Bijbel. De gelovigen zoeken hun heil dan ook bij "mijn vader - die is toen heel belangrijk geworden" (Theo), "de kerk" (Anna) en "de jeugdverenigingen van de kerk" (Rhodé). De atheïsten Hugo en Nico sluiten zich aan het begin van hun zoektocht aan bij typisch atheïstische organisaties omdat ze daar "gelijkgestemden" (Hugo) vinden die "gewoon precies zijn wat ik ben: humanistisch, atheïstisch en met wetenschap als basis" (Nico). De reden voor de voorkeur voor gelijkgestemden is volgens Rianne (gelovig) dat "als je hier het antwoord krijgt, je ervan uit kan gaan dat dit de waarheid is; en dat gaf een veilig gevoel". Haar antwoord is een motivatie voor het feit dat zij de antwoorden 
op haar vragen alleen zocht in de kerkelijke gemeente waarin ze opgroeide. In hun zoektocht raadplegen de respondenten dus uitsluitend gelijkgestemde bronnen, omdat ze die simpelweg meer vertrouwen. Hier blijkt opnieuw de invloed van het eigen wereldbeeld dat bepaalt dat individuen niet neutraal tegenover informatiebronnen staan. Dit geldt zelfs voor de gelovigen die later zijn afgehaakt. De opmerking van Ludo dat hij "toen [in zijn studententijd, nadat hij reflexief ging nadenken, AP] echt een hele gelovige jongen was" die tijdens zijn studie filosofie "dingen die strijdig waren met wat [hij] geloofde in twijfel trok" is exemplarisch. Het geloof bepaalt bij deze afhakers dus even sterk als bij de blijvers de aard van de reflexieve vragen en de bronnen waarin de antwoorden gezocht worden. Het verschil tussen de blijvers en de afhakers is dat de eersten overtuigd raken van de antwoorden die ze vinden op hun vragen en de laatsten niet.

\section{Verschillende plausibiliteitsstructuren}

Ook in het vinden van die zekerheid speelt het eigen wereldbeeld een grote rol. Atheïsten worden verzekerd van de plausibiliteit van hun levensbeschouwing als er wetenschappelijk bewijs voor is geleverd. Voor Nora en Norbert is het (atheïstisch) humanisme bijvoorbeeld zo overtuigend omdat het in hun ogen "een rationele keuze is", die Norbert als volgt toelicht:

Omdat we het allemaal leuk vinden om te leven in plaats van dood te zijn, geen pijn te hebben in plaats van wel pijn te hebben, [en het leuk vinden] als onze spullen niet worden gejat.

De atheïsten vinden een humanistisch wereldbeeld dus plausibel, omdat ze op basis van empirische observatie hebben vastgesteld dat de basisprincipes universeel worden nagestreefd. Ook de keuze tegen religie is voor Lars "niet een bepaalde mening" maar "een conclusie op basis van argumenten (...) [want] er zijn betere argumenten voor dat er geen God is dan voor dat er wel een God is". Lydia (spiritueel) is daarentegen overtuigd geraakt dat de oecumenische gemeenschap waarbij ze zich aangesloten heeft waarheid brengt omdat " het goed voelde, en aansluit bij hoe ik het voel en hoe ik denk dat het moet zijn". De spirituele respondenten geven steevast hun eigen gevoel op als reden voor de zekerheid over hun levensbeschouwing. Onder dat eigen gevoel liggen gedeelde criteria, die goed naar voren komen in de volgende uitleg van 
Edith over de zekerheid die ze vond tijdens haar tweejarige verblijf in de oecumenische kloostergemeenschap van Taizé:

Ik bloeide daar helemaal op! Want ik kon mezelf zijn. (...) Het leek alsof allerlei puzzelstukjes op zijn plek vielen (...) Want het was heel open, en je mocht twijfelen zoveel als je wilde maar je mocht ook juist heel erg gelovig zijn: alles kon eigenlijk.

Edith verwijst hier naar de belangrijke rol van haar eigen ervaring, maar stelt tevens de ruimte voor verschillende persoonlijke ervaringen als voorwaarde om zekerheid te krijgen over de spirituele levensovertuiging. Die ruimte past uiteraard bij de autoriteit die in het spirituele wereldbeeld wordt toegekend aan de eigen ervaring. Zowel de atheïstische als de spirituele respondenten zijn (opnieuw) overtuigd geraakt van hun eigen wereldbeeld. Atheïst Nico zegt zelfs "meer activistisch in zijn atheïsme" te zijn geworden, en ook de spirituele ervaringen van Lydia zijn nu "sterker" en "heftiger" dan vroeger. Onder invloed van hun eigen wereldbeeld is die zekerheid echter niet geënt op een universeel geldende, maar een wereldbeeld gebonden plausibiliteitsstructuur.

In de plausibiliteitsstructuur van de gelovigen is uiteraard "de bijbel altijd het startpunt" (Iris). Toch komt de Bijbel opmerkelijk weinig voor in de antwoorden die de blijvers geven als ik hen vraag wat zo "bevestigend" (Leo) heeft gewerkt voor hun geloof. "Het was de oprechtheid, de eenvoud (...) de liefde waarmee de moeder van mijn vriendin over de Heere Jezus sprak: dat overtuigde uiteindelijk", vertelt Rhodé. Oprechtheid van gelijkgestemde rolmodellen blijkt doorslaggevend te zijn voor de gelovigen. Met oprechtheid bedoelen ze wat Trilling $(1972,2)$ omschrijft als "congruence between avowal and actual feeling”. Of geloof oprecht is blijkt voor de gelovige respondenten uit twee gedragskenmerken van hun rolmodellen. In de beschrijving die Theo geeft van de oprechtheid van zijn vader vat hij die als volgt samen:

Dat hij de wereld van 'hoe het hoort' heel erg kan combineren met de wereld van 'hoe hij leeft' (...) [en] het beeld dat je vader als grote, stoere kerel zo bewogen, zo ernstvol kon zijn over dingen die hem aangingen in zijn relatie met God (...) daarvan had ik [de overtuiging]: dat kan niet anders zijn dan dat dat echt van God is.

Hoe belangrijk deze zichtbare overeenkomst tussen leer en leven en de emotionele betrokkenheid van rolmodellen is voor de gelovigen blijkt ook uit het verhaal van Roos. De vraag naar welke uitleg van de Bijbel "echt is" domineerde haar zoektocht. Het was vanwege haar ervaring dat haar familie "wel keurig in de kerk zat, maar verder niks uitstraalt" dat ze niet overtuigd raakte 
van hun interpretatie van de Bijbel. "Daar voel ik geen warmte, en daar zie ik geen liefde tot God (...) [en] dan denk ik: Dat is het zéker niet!”, zo herinnert ze zich haar toenemende twijfel over hun geloof. Tegelijkertijd raakt ze steeds meer overtuigd van het geloof van een goede (evangelische) vriend omdat ze "bij hem meer praktisch geloof, meer liefde tot God zag dan thuis".

Ook de meeste afhakers onder de gelovigen zoeken naar oprechtheid onder rolmodellen om de plausibiliteit van hun geloof te bevestigen, zoals blijkt uit de motivatie die Wim (nu atheïst) geeft voor zijn eerste twijfels over het gereformeerd vrijgemaakte geloof van zijn ouders. Die twijfels kwamen omdat hij "die mensen in de kerk allemaal zo op Farizeeërs vond lijken. Het waren hypocriete, wettische mensen, en dat vond ik toch een beetje bizar" zo vervolgt hij. Zijn twijfels hadden dus niets te maken met de irrationaliteit die hij nu als atheïst religie verwijt, maar met een gebrek in de plausibiliteitsstructuur van zijn oude religieuze levensbeschouwing. Het volgende voorbeeld van Saar (nu spiritueel) laat zien hoe de plausibiliteitseis van oprechtheid voor afhakers op dezelfde manier werkt als voor de blijvers. Tot haar tienertijd was Saar heel serieus bezig met haar geloof, waarbij haar vader haar rolmodel was. Als haar vriendinnen besluiten zich definitief te verbinden aan de baptistengemeenschap door zich te laten dopen, aarzelt Saar echter. Haar geloof was "niet by heart", wat ze in het volgende fragment als volgt uitlegt:

\footnotetext{
Het was mijn vaders [gedrag]. [Want] mijn vader mishandelde mij ook. En ik ben ook door hem seksueel misbruikt. Dus mijn vader had niet alle waarheid in pacht (...) dat was ontzettend dubbel (...) hij had een hoop theorie [maar] zelf voegde hij niet de daad bij het woord zeg maar (...) Dat heeft grote betekenis gehad voor mijn geloof, omdat mijn vader een soort boodschapper van God was voor mij (...) [dus] op het moment dat ik met mijn vader brak, brak ik ook met het geloof.
}

In dit fragment benoemt Saar heel expliciet hoe de onoprechtheid van haar religieuze rolmodel, hier ervaren door incongruentie tussen leer en leven, de plausibiliteit van haar religieuze wereldbeeld heeft ondermijnd. De afhakers ervaren vaak al gedurende hun hele leven op grote schaal onoprechtheid bij hun rolmodellen. "Ik miste altijd het hart, ik voelde nooit warmte", vertelt Linda bijvoorbeeld over haar religieuze opvoeders. Zolang ze hun geloof vanzelfsprekend vinden is dat geen probleem voor hen. Zodra ze er echter reflexief over gaan nadenken wordt de voor religieuze wereldbeelden geldige eis van oprechtheid relevant en wordt het ontbreken ervan een probleem. Een probleem, waarvan Anna zich herinnert dat ze "het ging oplossen" door te argumenteren dat "wat er in de bijbel staat gewoon het woord van mensen is 
dat corrupt is, maar dat God en Jezus daar niks aan kunnen doen”. Ze ging daarom "gewoon met God en Jezus verder en heeft de bijbel gedropt". Uit deze poging om het geloof te redden blijkt de kracht van het eigen wereldbeeld. Tegelijkertijd laat de oplossing van Anna zien dat het niet voldoen aan de door het geloof gestelde plausibiliteitseis van oprechtheid ertoe leidt dat het geloof langzaam wordt ondermijnd. Waar de autoriteit van de Bijbel in eerste instantie niet kritisch wordt bevraagd, gebeurt dat door het ontbreken van een oprecht nageleefde interpretatie daarvan op een gegeven moment wel.

De bevinding dat oprechtheid van rolmodellen voor gelovige respondenten wél en voor de spirituele en atheïstische respondenten niet belangrijk is, toont aan hoezeer bij elk wereldbeeld een eigen plausibiliteitsstructuur met een eigen dynamiek hoort. Bij atheïsme speelt oprechtheid van rolmodellen geen rol omdat het empirisch bewijs waarop hun plausibiliteitsstructuur steunt "verifieerbaar is door andere mensen", zo vertelt Norbert als hem dat wordt gevraagd. "Het werkt gewoon: Vliegtuigen vliegen, satellieten gaan om de maan, en we kunnen berekenen waarom deze tafel sterk genoeg is om te houden wat erop staat", legt ook Nico uit. Daarnaast vindt hij het "sterk aan wetenschap dat van een theorie waar 100 jaar aan is gewerkt en die vervolgens niet meer blijkt te werken wordt gezegd: Zonde van het werk maar het is niet anders [hij is verworpen]". De atheïsten voelen dus minder dan de gelovigen de noodzaak om te vertrouwen op de interpretatie van andere mensen, omdat zij het gevoel hebben dat de waarheden die ze aannemen controleerbaar zijn, en bovendien op elk moment vervangen kunnen worden als er bewijs van het tegendeel komt. Ook de spirituele respondenten zoeken niet naar oprechte rolmodellen om hun wereldbeeld te bevestigen. Dirk geeft zelfs de voorkeur aan het type van "de anti-held", omdat "van een held een soort normatieve boodschap uitgaat van 'zo moet je zijn', terwijl een anti-held aan jou als individu alle ruimte geeft om er te zijn”. Het typisch spirituele vertrouwen op de autoriteit van het zelf zorgt er dus voor dat spirituelen wispelturig gedrag meer legitiem achten dan oprechtheid en vroomheid. In tegenstelling tot de atheïsten en spirituelen ontlenen gelovigen hun autoriteit aan een entiteit buiten zichzelf, en zelfs buiten de immanente realiteit waarin ze leven. Ze kunnen hun waarheidsclaims daarom niet checken aan de hand van empirische observaties, en evenmin te rade gaan bij hun eigen ervaringen. Vertrouwen is voor hen daarom het enige middel om zekerheid te krijgen over de juistheid van hun wereldbeeld. Zoals ook Keane (2002) observeert onder protestanten, kan oprechtheid dit vertrouwen kweken en daarmee de plausibiliteit van een religieus wereldbeeld waarborgen. 


\section{Verdieping}

Degenen die bij hun oude levensovertuiging zijn gebleven zijn het opvallend eens over de vraag wat er veranderd is in hun levensbeschouwelijke identiteit. Rianne (gelovig) vat de verandering in haar leven samen als "dat je eerst tot de kern komt, en [dat] de bijzaken [later] nog wel komen”. Ook anderen spreken over "teruggaan naar de kern" (Roos, gelovig), de "behoefte hebben aan een overzicht" (Ralf, atheïst), en het vinden van "de link" (Lydia, spiritueel). In het volgende fragment (cursivering toegevoegd) schetst Ralf (atheïst) hoe die grotere nadruk op de kern van de eigen identiteit is ontstaan:

\footnotetext{
Er werd [vroeger] geen bredere visie verteld, en dat heb ik wel gemist. Dat ben ik later gaan proberen [te compenseren] door 'De geschiedenis van bijna alles' van Bill Bryson te gaan lezen. Dat is een dik boek, en ik hield helemaal niet van lezen. Maar omdat ik het hele plaatje wilde weten ben ik het toch gaan lezen (...) Omdat ik toch iets van een basis wilde weten van waaróm we doen wat we doen.
}

Dit citaat laat zien dat het zoeken naar de 'basis', de diepere bedoeling achter de normen en waarden die hij altijd voor vanzelfsprekend had gevonden, voor Ralf een logisch gevolg is van zijn reflexieve zoektocht. Rhodé (gelovig) legt dezelfde link tussen haar reflexieve vragen en een toenemende aandacht voor de kern van haar geloof als ze vertelt over haar veranderde visie op het kijken van films. Toen ze zich af ging vragen waarom het kijken van films verboden is, kwam ze tot de conclusie dat "het gaat om de inhoud en niet slechts om de vorm". Naar eigen zeggen is ze in die tijd "dingen meer gaan beoordelen op: Wat is nou echt het probleem ervan? Waar gaat het nou echt om?".

Wat wordt gedefinieerd als de kern van de eigen identiteit hangt uiteraard samen met het eigen wereldbeeld. "God liefhebben boven alles, en je naaste als jezelf: dat is de kern”, zo verwoordt Roos de ideeën van gelovigen daarover. Atheïsme daarentegen "gaat uit van de kracht van de mens en van het hier en nu", ontdekte Nora. Voor spirituelen is "de basis (...) de totale scoop [aan spirituele tradities]", vat Erwin samen. Toen hij "daarover nadacht realiseerde [hij zich] de breedte" ervan en "brak het ook helemaal open”. Deze uitspraak van Erwin is veelzeggend, omdat die laat zien dat, inherent aan de spirituele nadruk op holisme, het ontdekken van de kern voor hem geen versmalling maar juist een verbreding inhoudt. Daarom noemen zowel Trijntje als Lydia het "de link" die ze ontdekten tussen de verschillende elementen van hun identiteit. Kortom, voor de gelovige, atheïstische én spirituele respondenten geldt dat reflexiviteit ervoor gezorgd heeft dat ze op zoek zijn gegaan 
naar de diepere betekenis achter normen en tradities die tot op dat moment vanzelfsprekend voor hen waren. Hun identiteit wordt daardoor meer kerngerelateerd dan voorheen.

\section{Purificatie}

In praktische zin vond er ook "een grote verandering” plaats, omdat Theo (gelovig) naar eigen zeggen "van twee werelden in [z]ijn leven weer één wereld makkte”. De term 'leven in twee werelden' komt veel voor onder de gelovige respondenten en verwoordt de huidige overtuiging dat hun gedrag vroeger niet consistent was met hun wereldbeeld. Theo ging in zijn tienerjaren bijvoorbeeld naar de bioscoop en bezocht cafés, terwijl hij tegelijkertijd niet twijfelde aan zijn geloof dat beide zaken verbiedt. In het volgende fragment legt hij uit waarom hij nu denkt dat hij zich vroeger zo gedroeg:

Ik wist heus wel dat het niet klopte. (...) Alleen ik deed er gewoon niks mee. Voor mezelf dacht ik niet meer na over wat ik wel en niet deed of wat ik wel of niet goed vond, of waar ik voor stond. Want ik stond eigenlijk nergens voor op dat moment. (...) Ik denk dat ik tot en met die tijd heel erg een meeloper ben geweest. Heel erg de groep gevolgd. Ja, dat is niet tof, maar het is wel de waarheid. En dat heeft mij later juist een hele erge anti-(volgzame) houding gegeven.

Dit citaat illustreert hoe de vanzelfsprekendheid waarmee de gelovige respondenten vroeger naar hun geloof keken ervoor zorgde dat ze minder nadachten of hun gedrag consistent was met hun wereldbeeld, en hun medegelovigen meer blindelings volgden. Als ze echter reflexief gaan nadenken en de kern van hun geloof meer gaan benadrukken, worden de inconsistenties als het ware uitgevonden en gaan ze een probleem vormen. Theo is op dat moment dan ook abrupt gestopt met zijn oude gedrag. Het idee dat er een transformatie heeft plaatsgevonden van leven in twee werelden naar leven in één wereld duidt dus in feite op een purificatie van de levensbeschouwelijke identiteit. Met purificatie wordt kortweg bedoeld dat men de tradities en ideeën die men altijd als vanzelfsprekend heeft beschouwd kritisch gaat toetsen op de relatie met de kern van het eigen wereldbeeld, en de levensbeschouwelijke identiteit zuivert van gevonden inconsistenties. Die purificatie is bijvoorbeeld zichtbaar in de kritische houding die gelovigen ontwikkelen naar "gevestigde gewoonten” (Rhodé). Regels zoals het hebben van lang haar voor vrouwen vindt Rhodé nu "echt nergens over gaan [want] dat maakt het verschil niet (...) 
het gaat om naastenliefde en de liefde tot God", zo legt ze uit. Ze wijst deze regels dus af omdat ze volgens haar niet uit de kern voortvloeien. Anderzijds is ze "nog steeds, maar nu nog overtuigender, tegen echtscheiding”, omdat ze "de bedoeling" nu inziet, en "er meer invulling aan ging geven vanuit wat God wil”.

Ook bij de atheïsten en spirituelen leidt de reflexieve zoektocht tot purificatie van de levensbeschouwelijke identiteit. Ik zal dat illustreren aan de hand van twee voorbeelden. Het voorbeeld van Nico (atheïst) gaat over zijn beslissing om veganist te worden, een beslissing die hij als volgt motiveert:

Als je je wat meer verdiept in het humanisme dan kom je er achter (...) dat ook wij als niet religieuzen nog dat scheppingsverhaal uit Genesis als basis hebben als we spreken over mens en dier (...) we vinden dat er [een verschil tussen] mens en dier is, terwijl we biologisch gezien gewoon één van de dieren zijn (...) We geloven allemaal in Darwin, maar handelen nog vanuit Genesis. Dat klopt niet, dat is een soort morele schizofrenie (...) Toen [ik dat besefte] ben ik gestopt met vlees eten (...) en sinds die dag begrijp ik ook niet dat ik dat ooit normaal heb gevonden.

De uitleg van Nico demonstreert hoe verdieping in zijn atheïstische wereldbeeld inconsistenties in zijn identiteit aan het licht brengt. Zoals gelovigen het 'leven in twee werelden' gaan aanpakken, gaat Nico de ontdekte 'morele schizofrenie' oplossen door zijn identiteit meer in overeenstemming te brengen met de basisprincipes van zijn wereldbeeld. Het tweede voorbeeld uit het interview met Lydia laat zien dat het bij spirituelen niet anders werkt. Nadat ze zich "wat meer is gaan verdiepen in hatha yoga" en "de link" tussen alle losse elementen uit haar identiteit heeft gevonden kon ze haar "leven op een andere manier inrichten". Hoewel ze "relatief vrij" is opgevoed, heeft "het gevoel alle dingetjes aan elkaar te hebben geknoopt" ervoor gezorgd dat "dat het super gedefinieerde een beetje weg is". Met dat laatste bedoelt ze dat ze het concept God breder is gaan invullen dan louter vanuit de liberaal katholieke traditie waarin ze is opgegroeid. Aangezien holisme een spiritueel dogma is, betekent Lydia's toenemende openheid een purificatie van de spirituele identiteit, die ook bij haar voortkomt uit de verdieping in het eigen wereldbeeld.

Deze purificatie is voor enkele afhakers paradoxaal genoeg een belangrijke oorzaak van de ondermijning van hun geloof. In tegenstelling tot het eerste type afhakers, wijt dit tweede type het verlies van hun geloof niet aan onoprechtheid van rolmodellen. Zoals blijkt uit het volgende fragment uit het interview met Lars (nu atheïst) ligt het probleem voor hen in de manier waarop andere gelovigen met reflexiviteit omgaan: 
Dan gaan ze zo'n vraag stellen van: 'Ja, maar is dat wel waar?’ Wat heb ik me geërgerd aan dat die mensen alleen maar antwoorden zoeken in de bijbel! Terwijl ik dát fundament nou juist betwijfelde. (...) [want] waarom is dat de basis? Omdat in de basis staat dat het de basis is? (...) Dat was echt niet naar mijn tevredenheid. Ik wilde bewijs, want ik had toch wel een beetje een rationele insteek.

Het opmerkelijke is dat Lars de Bijbel betrekt in zijn reflexieve vragen, terwijl de andere gelovigen dat niet doen. Uit zijn verwijzing naar 'bewijs' en 'een rationele insteek' blijkt dat hij dat doet omdat hij een atheïstische plausibiliteitsstructuur hanteert. Ook Milan gebruikt een spiritueel criterium als hij zegt dat zijn geloof is ondergraven omdat hij "het gevoel had dat je heel veel dingen moest laten die [hij] niet wilde laten". Hij baseert zich daarmee op de autoriteit van zijn eigen gevoel en niet op de onder gelovigen geaccepteerde autoriteit van de Bijbel of de kerk.

Als ik Norbert (nu atheïst) vraag waarom alleen empirisch bewijs zijn religieuze wereldbeeld kon legitimeren verwijst hij opmerkelijk genoeg naar zijn gelovige opvoeding en vertelt:

Mijn vader is zijn hele leven politierechercheur geweest, en die heeft mij altijd gezegd (...) dat dingen moeten kloppen en het bewijsmateriaal goed moet zijn (...) Maar hij had een uitsluitingsclausule voor God: Hier op aarde moesten dingen kloppen en praatte hij over bewijslast, maar God kan [volgens hem] de natuurwetten buigen (...) Ik vond die 'special pleading' voor God raar.

Zoals blijkt uit dit antwoord, is het probleem voor dit tweede type afhakers niet het leren kennen van andere levensovertuigingen, maar het ontdekken dat er inconsistentie bestaat binnen hun eigen levensovertuiging. Ze zijn opgegroeid met wat Emma (nu spiritueel) “twee takjes" binnen het wereldbeeld van haar moeder noemt. Zolang ze hun wereldbeeld vanzelfsprekend vonden, is het naast elkaar bestaan van deze 'twee takjes' voor hen geen probleem. Lars zegt bijvoorbeeld dat hij "altijd rationeel is geweest", maar tegelijkertijd het religieuze verhaal vroeger "gewoon voor waar aannam". Pas in de periode dat Milan (spiritueel) reflexieve vragen gaat stellen, gaat hij ervaren dat hij "gewoon dubbel was in dingen". Bij dit tweede type afvalligen zorgt het purificerende effect van reflexiviteit er dus voor dat ze afstand nemen van het religieuze ten faveure van het atheïstische of spirituele element in hun levensbeschouwing. 


\section{Conclusie}

De belangrijkste bevinding uit de analyse van de levensbeschouwelijke trajecten van gelovigen, atheïsten en spirituelen is dat religieuze reflexiviteit resulteert in hernieuwde zekerheid over en purificatie van de eigen levensbeschouwelijke identiteit. Dit gaat lijnrecht in tegen de gangbare relativeringstheorie waarin wordt verondersteld dat reflexiviteit eindigt in blijvende onzekerheid en levensbeschouwelijk relativisme (e.g. Berger 2014; Marti 2015). Uit de vergelijking tussen verschillende levensovertuigingen blijkt bovendien dat purificatie niet alleen voorkomt onder fundamentalistische gelovigen en nieuwe atheïsten, maar ook onder aanhangers van nieuwe spiritualiteit (cf. Roeland et al. 2010). De purificatie van de laatste groep wordt vaak over het hoofd gezien, of ten onrechte aangemerkt als bewijs voor onzekerheid en relativisme (e.g. Berger \& Zijderveld 2009). Omdat holisme een centraal dogma is, is toenemende 'bricolage' van religieuze tradities echter geen signaal van relativering maar van purificatie van de spirituele levensovertuiging.

Dat reflexiviteit de levensbeschouwing purificeert en verstevigt in plaats van relativeert en verzwakt komt door de invloed die het eigen wereldbeeld op drie verschillende manieren uitoefent op het omgaan met die reflexiviteit. In de eerste plaats beperkt dat eigen wereldbeeld de reflexieve vragen. De centrale dogma's worden niet ter discussie gesteld, maar dienen juist als ijkpunt voor de zoektocht die volgt. In de tweede plaats bepaalt het eigen wereldbeeld de bronnen waarin de antwoorden worden gezocht. Bronnen worden door de gekleurde blik die het wereldbeeld op de werkelijkheid heeft nooit als neutraal gepercipieerd. Hierdoor worden antwoorden alleen gezocht binnen de eigen levensbeschouwing en onder gelijkgestemden. In de derde plaats blijkt elk wereldbeeld een eigen plausibiliteitsstructuur te hanteren waarmee de zekerheid van de eigen levensbeschouwing wordt bevestigd. Atheïsten vinden die zekerheid in wetenschappelijk bewijs voor hun aannames, terwijl de spirituele plausibiliteitsstructuur is gebaseerd op (vrijheid voor) de eigen ervaring van individuen. De gelovigen vinden dat hun geloof wordt bevestigd als rolmodellen een oprechte interpretatie van de Bijbel kunnen geven. Vanwege de invloed die het eigen wereldbeeld uitoefent, is de reflexieve zoektocht van individuen in een pluralistische samenleving in feite enkel een verdieping in de kern van dat eigen wereldbeeld. De toegenomen kennis over die kern brengt met zich mee dat bestaande normen en praktijken eraan worden getoetst en indien nodig gepurificeerd. Die invloed van het eigen wereldbeeld op religieuze reflexiviteit is zo groot, dat het de twijfel aan de eigen levensbeschouwing ombuigt naar nieuwe zekerheid en purificatie ervan. Purificatie 
is dus geen ontkenning van de relativerende werking van reflexiviteit, maar een logisch gevolg van door het eigen wereldbeeld ingeperkte reflexiviteit zelf.

Het eigen gelovige wereldbeeld speelt ook een belangrijke rol in de ondermijning van de religieuze levensovertuiging bij de afhakers. Voor het eerste type afhakers verliest religie haar legitimiteit omdat niet wordt voldaan aan de typische religieuze plausibiliteitseis van oprechtheid van religieuze rolmodellen. In het tweede traject is het de tweeledigheid in het eigen wereldbeeld die boven tafel komt en problematisch wordt door een reflexieve houding en de daarmee gepaard gaande neiging tot purificatie. Voor de afhakers in beide trajecten zorgt een intern en geloofseigen probleem er dus voor dat hun geloof steeds minder legitiem wordt. Individuen gaan niet twijfelen omdat een ontwikkeling als religieus pluralisme hen dwingt om andere wereldbeelden te overwegen, maar omdat het oude wereldbeeld niet gezond genoeg blijkt om de verandering naar reflexief denken succesvol te verwerken.

De bevinding dat zowel purificatie als geloofsafval binnen de eigen (oude) levensbeschouwing plaatsvindt, laat zien dat er een alternatieve, meer culturele benadering nodig is in het bredere debat over religieuze verandering. Vaak wordt religieuze verandering toegeschreven aan allerlei externe factoren zoals individualisering en rationalisering. Om religieuze verandering echter goed te begrijpen is de visie die Campbell (2007) bepleit in zijn studie naar de toenemende populariteit van het oosterse denken in het westen zinvol. Externe ontwikkelingen in de samenleving hebben volgens Campbell geen onafhankelijke invloed op de religieuze identiteit, maar worden geïnterpreteerd vanuit het eigen betekeniskader en op een creatieve manier verwerkt in het eigen wereldbeeld. Daarom moet volgens hem bij het bestuderen van religieuze veranderingen de aandacht veel meer gericht worden op het eigen (oude) wereldbeeld. Zoals uit de analyse in dit artikel blijkt kan die invloed van de gekleurde bril van het eigen wereldbeeld een bijna omgekeerde uitwerking hebben op de religieuze levensbeschouwing dan men zonder die invloed van het eigen wereldbeeld zou verwachten.

\section{Noten}

1 Zie bijvoorbeeld zijn reactie op een artikel van filosoof Ger Groot op https://www.humanistischverbond.nl/er-is-wel-degelijk-zelotisch-humanisme-innederland/.

2 De interviews vormen de empirische basis van mijn promotie-onderzoek, waarin veel breder wordt ingegaan op de invloed van het eigen wereldbeeld op de definiëring van religieus pluralisme in het algemeen, op religieuze veranderingstrajecten, en op de rol van religieus pluralisme in die trajecten. De vraag die in dit artikel aan de orde komt 
is het resultaat van de slotanalyse van mijn proefschrift waarin de rol van dat eigen wereldbeeld in het bepalen van de effecten van religieuze reflexiviteit voor de levensovertuiging van individuen wordt bestudeerd.

3 Berger lijkt dat soms te beweren als hij bijvoorbeeld zegt dat relativering wel het 'hoe' maar niet het 'wat' van het wereldbeeld verandert (zie bijvoorbeeld Berger, 2014: 32).

4 Dit is een citaat uit de Bijbel, zie: Mattheus 22: 35-40, Markus 12: 28-34 en Lukas 10: 27 .

\section{Literatuur}

Ammerman, N.T. (1987),

Bible Believers: Fundamentalists in the Modern World, New Brunswick: Rutgers University Press.

Aupers, S. \& D. Houtman (2006),

Beyond the Spiritual Supermarket: The Social and Public Significance of New Age Spirituality, in: Journal of Contemporary Religion, 21 (2), 201-222.

Beekers, D. (2015),

Precarious Piety: Pursuits of Faith among Young Muslims \& Christians in the Netherlands, Proefschrift VU Amsterdam.

Berger, P.L. (1969),

The Sacred Canopy: Elements of a Sociological Theory of Religion, New York: Bantam Doubleday Dell Publishing Group Inc.

Berger, P.L. (1979),

The Heretical Imperative: Contemporary Possibilities of Religious Affirmation, New York: Anchor Press.

Berger, P.L. (2014),

The Many Altars of Modernity: Towards a Paradigm for Religion in a Pluralist Age, Boston/Berlin: De Gruyter.

Berger, P.L., B. Berger \& H. Kellner (1973),

The Homeless Mind: Modernization and Consciousness, New York, NY: Random House.

Berger, P.L., \& Th. Luckmann (1966),

The Social Construction of Reality, Garden City: Doubleday.

Berger, P. L., \& A. C. Zijderveld (2009),

In Praise of Doubt: How to have Convictions without becoming a Fanatic, HarperCollins E-books.

Bruce, S. (2002),

God is dead: Secularization in the West, Oxford: Blackwell.

Bullivant, S. (2012),

Not so Indifferent after all? Self-Conscious Atheism and the Secularisation Thesis, in:

Approaching Religion, 2 (1), 100-106. 
Campbell, C. (2007),

The Easternization of the West: A Thematic Account of Cultural change in the Modern Era, Boulder: Paradigm Publishers.

Chaves (1994),

Secularization as Declining Religious Authority, in: Social Forces, 72 (3), 749-774.

Cimino, R., \& C. Smith (2007),

Secular Humanism and Atheism beyond Progressive Secularism, in: Sociology of Religion, 68 (4), 407-424.

Houtman, D. \& P. Tromp (2020),

The Post-Christian Spirituality Scale (PCSS): Misconceptions, Obstacles, Prospects, in: Wink, A. Ai. P., R.F. Paloutzian \& K.A. Harris (eds.), Assessing Spirituality in a Diverse World, Cham: Springer International (in press).

Hunsberger, B. E. \& B. Altemeyer (2006),

Atheists: A Groundbreaking Study of America's Nonbelievers, New York: Prometheus Books.

Keane, W. (2002),

Sincerity, Modernity, and the Protestants, in: Cultural Anthropology, 17 (1), 65-92.

Lawrence, B.B. (1989),

Defenders of God: The Fundamentalist Revolt against the Modern Age, San Francisco: Harper \& Row.

Lechner, F.J. (1991),

The Case Against Secularization Theory: A Rebuttal, in: Social Forces, 69 (4), 1103-1119.

Martí, G. (2015),

Religious Reflexivity: The Effect of Continual Novelty and Diversity on Individual religiosity, in: Sociology of Religion, 76 (1), 1-13.

Peek, L. (2005),

Becoming Muslim: The Development of a Religious Identity, in: Sociology of Religion, 66 (3), $215-242$.

Pfadenhauer, M. (2016),

In-Between Spaces. Pluralism and Hybridity as Elements of a New Paradigm for Religion in the Modern Age, in: Human Studies, 39 (1), 147-159.

Rambo, L.R. (1993),

Understanding Religious Conversion, New Haven/London: Yale University Press.

Ribberink, E. \& D. Houtman (2010),

'Te ongelovig om atheïst te zijn': Over de-privatisering van ongeloof, in: Religie \& Samenleving, 5 (3), 209-226.

Ribberink, E., P. Achterberg \& D. Houtman (2013),

Deprivatization of Disbelief? Non-religiosity and Anti-Religiosity in 14 Western European Countries, in: Politics and Religion, 6, 101-120. 
Roeland, J., S. Aupers, D. Houtman, M. De Koning \& I. Noomen (2010),

The Quest for Religious Purity in New Age, Evangelicalism and Islam: Religious Renditions of Dutch Youth and the Luckmann Legacy, in: Annual Review of Sociology of Religion, 1, 289-306.

Smith, C. (1998),

American Evangelicalism: Embattled and Thriving, University of Chicago Press.

Smith, J.M. (2011),

Becoming an Atheist in America: Constructing Identity and Meaning from the Rejection of Theism, in: Sociology of Religion, 72 (2), 215-237.

Trilling, L. (1972),

Sincerity and Authenticity, New York: Harvard University Press.

Wilson, B. (1982),

Religion in Sociological Perspective, Oxford: Oxford University Press.

Woodhead, L. \& P. Heelas (2000),

Religion in Modern Times: An Interpretive Anthology, Oxford, United Kingdom: Blackwell Publishers.

Yamane, D. (1997),

Secularization on Trial: In Defense of a Neosecularization Paradigm, in: Journal for the Scientific Study of Religion, 36 (1), 109-122. 


\section{Bijlage: Categorisch overzicht ontwikkeling wereldbeeld respondenten}
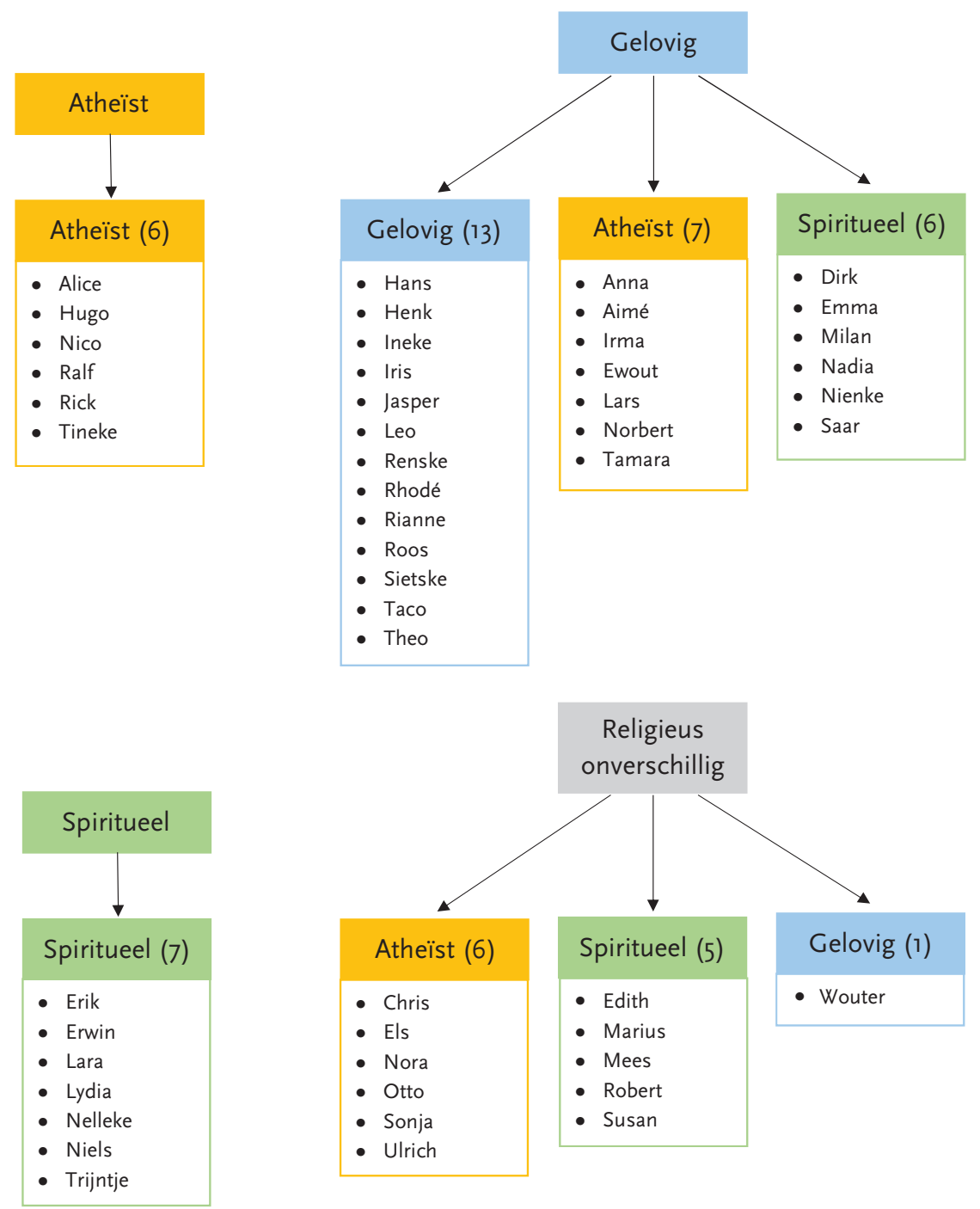

Religie Q Samenleving, Jrg. 15, nr. 2 (mei 2020) 